\title{
PENGGUNAAN METODE PEMBELAJARAN ROLE PLAYING DALAM MENUMBUHKAN MOTIVASI BELAJAR PADA PEMBELAJARAN SEJARAH
}

\author{
Fathurrahman \\ Program Studi Pendidikan Sejarah FKIP Universitas Lambung Mangkurat \\ Banjarmasin \\ Email: rfathur235@gmail.com
}

\begin{abstract}
Abstrak: Pembelajaran sejarah yang digunakan oleh guru sejarah di sekolah masih kurang menarik. Hal demikian berimbas pada kurangnya motivasi peserta didik dalam pembelajaran sejarah. Padahal pengetahuan sejarah sangat penting untuk dipelajari selain fundamental dalam pembentukan identitas nasional juga sebagai sumber inspirasi yang sarat makna dalam pengembangan kesadaran sejarah terhadap peserta didik.

Metode pembelajaran Role Playing salah satu metode pembelajaran yang bisa diterapkan oleh guru dalam menumbuhkan motivasi belajar sejarah, dimana metode ini mencoba mengeksplorasi hubungan interaktif guru dan peserta didik, peserta didik dan guru, maupun antar peserta didik dengan cara memperagakan dan mendiskusikan sehingga secara tidak langsung peserta didik dapat mengeksplorasi perasaan, sikap, nilai, dan berbagai strategi pemecahan masalah.
\end{abstract}

Kata kunci : pembelajaran sejarah, metode pembelajaran role playing, motivasi belajar

\section{PENDAHULUAN}

Dalam proses pendidikan, komponen yang dianggap paling berpengaruh adalah guru. Guru adalah orang yang berwenang dan memiliki tanggung jawab terhadap pendidikan peserta didik, baik di sekolah ataupun di luar sekolah (Leba \& Padmomartono, 2013). Karena guru memiliki tanggung jawab terhadap pendidikan peserta didik, maka dari itu guru harus dituntut berkualitas dan professional. Seorang guru harus bisa menciptakan suasana proses pembelajaran yang menyenangkan. Dalam proses pembelajaran guru tidak hanya memberikan materi saja, namun juga menjadi motivator bagi peserta didiknya. Akan tetapi, yang terjadi pada proses pembelajaran sejarah guru masih kurang bisa membuat suasana pembelajaran yang menyenangkan. Oleh karena itulah, guru harus menumbuhkan motivasi belajar peserta didiknya. Menciptakan suasana belajar yang menyenangkan merupakan salah satu cara menumbuhkan motivasi belajar peserta didik (Sanjaya, 2006). 
Untuk bisa membuat suasana menyenangkan guru harus menerapkan motode pembelajaran dalam proses pembelajarannya. Sanjaya (2010:147) menyatakan "metode adalah cara untuk mengimplementasikan rencana yang sudah disusun dalam kegiatan nyata agar tujuan yang telah disusun tercapai secara optimal". Pada pembelajaran dapat digunakan metode-metode tertentu agar kegiatan pembelajaran lebih bervariasi. Seperti yang dipaparkan oleh Roestiyah (2008:1) bahwa "metode mengajar adalah teknik penyajian yang dikuasai guru untuk mengajar atau menyajikan bahan pelajaran kepada peserta didik di dalam kelas, agar pelajaran tersebut dapat ditangkap, dipahami, digunakan oleh peserta didik dengan baik". Banyak metode pembelajaran yang bisa diterapkan oleh guru untuk meningkatkan motivasi belajar peserta didik antara lain motode problem solving, diskusi, demonstrasi, role playing, make match dan sebagainya.

Salah satu metode yang dapat diterapkan pada pembelajaran sejarah agar proses pembelajarannya bisa membuat peserta didik efektif, menyenangkan dan termotivasi adalah metode pembelajaran bermain peran (Role Paying). Dimana guru bertindak sebagai fasilitator dalam proses pembelajaran yang merancang pemeranan, mempersiapkan peralatan, dan menciptakan suasana yang tepat agar Role Playing dapat berlangsung dengan optimal dengan harapan dapat menumbuhkan daya tarik peserta didik dalam mengikuti pelajaran, menjalin interaksi yang baik, antara guru dan peserta didik, peserta didik dan guru, maupun antar peserta didik, serta menciptkan suasana belajar yang menyenangkan sehingga dapat menumbuhkan motivasi peserta didik untuk belajar (Suryaningtyas, 2014:6).

Mengingat pentingnya proses pembelajaran tersebut, maka selayaknya guru bisa menerapkan metode pembelajaran Role Playing untuk mendukung dalam menumbuhkan motivasi belajar peserta didik dalam pembelajaran sejarah. Karena metode ini akan membantu guru dalam proses pembelajaran sejarah di sekolah.

\section{PENTINGNYA PEMBELAJARAN SEJARAH}

Mata pelajaran yang dekat dengan pembangunan karakter bangsa adalah mata pelajaran sejarah, karena mengandung substansi untuk memahami jati diri bangsa (Putro, 2016:326). Selain itu sejarah dapat memberikan inspirasi kepada kita tentang gagasan dan konsep yang dapat digunakan untuk memecahkan persoalan-persoalan masa kini, dengan mempelajari sejarah orang dapat menghindari kegagalan dan kesalahan yang pernah sebelumnya dilakukan serta menemukan sumber-sumber baru untuk merumuskan visi masa depan (Prawitasari, 2015).

Sejarah diartikan bukan sekedar rangkaian peristiwa melainkan lingkaran peristiwa yang terentang dalam lilitan benang gagasan. Sederhana gagasan kemudian ditafsirkan sebagai 
dasar sebuah tindakan (perilaku) berada di belakang setiap kejadian sehingga peristiwa dianggap penting. Gagagasan atau ide dijadikan motor untuk memberikan motivasi manusia (masyarakat) mencapai cita, sesuai dengan jiwa zaman (Mutiani, dkk, 2019:11).

Mempelajari sejarah secara tidak langsung berarti berusaha memahami bagaimana pola dan tindakan manusia sesuai dengan cara pandang dan tata nilai bermasyarakat manusia pada masa lalu. Dengan demikian mempelajari sejarah berarti juga mempelajari bagaimana semangat, ide dan semangat jiwa manusia pada masanya (Susanto, 2014:397).

Pembelajaran Sejarah adalah proses belajar mengajar yang berkaitan dengan materi sejarah. Tujuan mempelajari sejarah menurut Kasmadi (1996:13) adalah untuk menanamkan semangat kebangsaan, cinta tanah air, bangsa dan negara, serta sadar untuk menjawab untuk apa ia dilahirkan.

Kochar (2008) menjelaskan sasaran utama pembelajaran sejarah di SMA adalah sebagai berikut:

1. Meningkatkan pemahaman terhadap proses perubahan dan perkembangan yang dilalui umat manusia sehingga mampu mencapai tahap perkembangan yang sekarang ini. Peradaban modern yang dicapai pada saat ini merupakan hasil proses perkembangan yang panjang. Sejarah merupakan satu-satunya mata pelajaran yang mampu menguraikan proses tersebut.

2. Meningkatkan pemahaman terhadap akar peradaban manusia dan penghargaan terhadap kesatuan dasar manusia. Semua peradaban besar dunia memiliki akar yang sama di samping berbagai karakteristik lokal, kebanyakan adalah unsur-unsur yang menunjukkan kesatuan dasar manusia. Salah satu sasaran utama sejarah pada sisi ini adalah menekankan dasar tersebut.

3. Menghargai berbagai sumbangan yang diberikan oleh semua kebudayaan pada peradaban manusia secara keseluruhan. Kebudayaan setiap bangsa telah menyumbangkan dengan berbagai cara terhadap peradaban secara keseluruhan. Mata pelajaran sejarah membawa pengetahuan ini kepada para peserta didik.

4. Memperkokoh pemahaman bahwa interaksi saling menguntungkan antar berbagai kebudayaan merupakan faktor yang penting dalam kemajuan kehidupan manusia.

5. Memberikan kemudahan kepada peserta didik yang berminat mempelajari sejarah suatu negara dalam kaitannya dengan sejarah umat manusia secara keseluruhan.

Pembelajaran sejarah yang baik akan membentuk pemahaman sejarah. Pemahaman sejarah merupakan kecenderungan berpikir yang merefleksikan nilai-nilai positif dari peristiwa sejarah dalam kehidupan sehari-hari, sehingga kita menjadi lebih bijak dalam melihat dan memberikan respon terhadap berbagai masalah kehidupan. Pemahaman sejarah memberi 
pentunjuk kepada kita untuk melihat serangkaian peristiwa masa lalu sebagai sistem tindakan masa lalu sesuai dengan jiwa jamannya, akan tetapi memiliki sekumpulan nilai edukatif terhadap kehidupan sekarang dan akan datang (Susanto, 2014:36).

Dalam konteks membangun nasionalisme, pembelajaran sejarah berkarakter haruslah dibangun dengan memulai materi yang "dekat" dengan peserta didik. Dalam konteks pembelajaran sejarah berarti, disamping materi sejarah bersifat nasional, materi muatan (sejarah) lokal merupakan keharusan, sebab dari muatan (sejarah) lokal dibangun sejarah nasional dan nasionalisme Indonesia. Dengan kata lain, muatan (sejarah) lokal menjadi titik pijak bagi membangun karakter nasionalisme (Abbas, 2016).

Pemahaman sejarah daerah yang merupakan sejarah perjuangan dan persepsi terhadap keberagaman budaya memberikan kontribusi bagi sikap nasionalisme karena kedua variabel tersebut adalah unsur-unsur pokok dalam pengembangan sikap nasionalisme Indonesia, dengan kata lain sintesa dari keduanya akan mereflesikan sikap nasionalisme Indonesia (Susanto, 2017:49).

Perlu diketahui bahwa pembelajaran sejarah merupakan salah satu komponen yang penting dari sistem kegiatan pendidikan, di mana dalam pembelajaran sejarah adalah sarana yang efektif untuk meningkatkan integritas dan kepribadian bangsa melalui proses mengajar. Dalam konteks yang lebih sederhana, pembelajaran sejarah sebagai sub sistem dari sistem kegiatan pendidikan, merupakan usaha pembandingan dalam kegiatan belajar, yang menunjuk pada pengaturan dan pengorganisasian lingkungan belajar mengajar sehingga mendorong serta menumbuhkan motivasi peserta didik untuk belajar dan mengembangkan diri (Astuti, 2016:40).

\section{Langkah-Langkah Penerapan Metode Role Playing}

Menerapkan metode Role Playing dalam pembelajaran perlu diperhatikan langkahlangkahnya. Tujuannya agar memudahkan guru dan peserta didik dalam praktik menggunakan metode Role Playing. Roestiyah (2008:91) menyatakan langkah-langkah penerapan metode Role Playing yaitu:

1. Guru harus menerangkan kepada peserta didik untuk memperkenalkan teknik ini, peserta didik diharapkan mampu memecahkan masalah hubungan sosial yang aktual di masyarakat, kemudian guru menunjuk beberapa peserta didik yang akan berperan, masingmasing akan mencari pemecahan masalah sesuai dengan peranya dan peserta didik yang lain menjadi penonton dengan tugas-tugas tertentu pula.

2. Guru harus memilih masalah yang urgen, sehingga menarik minat peserta didik. Guru menjelaskan dengan menarik, sehingga peserta didik dapat terangsang untuk berusaha memecahkan masalah itu. 
3. Agar peserta didik memahami peristiwanya, maka guru harus dapat menceritakan sambil mengatur adegan yang pertama.

4. Bila ada kesediaan sukarela dari peserta didik untuk berperan, harap ditanggapi tetapi guru harus mempertimbangkan apakah peserta didik tersebut tepat melakukan peran tersebut.

5. Jelaskan pada pemeran-pemeran itu sebaik-baiknya, sehingga mereka tahu tugas perannya, menguasai dalam bermimik maupun berdialog.

6. Peserta didik yang tidak turut harus menjadi penonton yang aktif, di samping mendengar dan melihat, mereka harus bisa memberi saran dan kritik setelah pemeranan selesai.

7. Apabila peserta didik belum terbiasa, perlu dibantu guru dalam menimbulkan kalimat pertama dalam dialog.

8. Setelah pemeranan tersebut dalam situasi klimaks, maka harus dihentikan, agar kemungkinan-kemungkinan pemecahan masalah dapat didiskusikan secara umum. Sehingga para penonton ada kesempatan untuk berpendapat, menilai permainan dan sebagainya. Pemeranan dapat dihentikan pula bila sedang menemui jalan buntu.

9. Sebagai tindak lanjut dari hasil diskusi, walau mungkin masalahnya belum terpecahkan, maka perlu dibuka tanya jawab, diskusi atau membuat keterangan yang berbentuk sandiwara.

Sedangkan menurut Barkley, dkk (2012:228) langkah-langkah dalam penggunaan metode Role Playing adalah sebagai berikut:

1. Membentuk kelompok.

2. Guru menyusun/menyiapkan skenario yang akan ditampilkan dan beri batas waktu untuk mendiskusikan situasi yang dihadapi.

3. Meminta beberapa peserta didik untuk memainkan sebuah peran (penjelasan tentang Role Playing).

4. Informasikan mengenai batas waktu.

5. Minta peserta didik untuk membangun permainan.

6. Diskusi dalam kelompok-kelompok kecil dengan keseluruhan anggota kelas.

7. Membangun kembali permainan

Dari berbagai pendapat mengenai langkah-langkah dalam metode Role Playing dapat disimpulkan bahwa metode ini sengaja didesign untuk melibatkan peserta didik menggali berbagai informasi baik penguasaan materi pelajaran maupun karakter-karakter dengan memperagakan suatu peran untuk mencapai tujuan dengan bantuan kelompok. 


\section{Cara Menumbuhkan Motivasi Belajar}

Fathurrohman, dkk (2007:20) mengatakan terdapat beberapa cara untuk meningkatkan motivasi belajar peserta didik yaitu sebagai berikut:

1. Menjelaskan tujuan kepada peserta didik

Pada permulaan belajar mengajar seharusnya terlebih dahulu seorang guru menjelaskan mengenai tujuan instruksional khusus yang akan dicapainya kepada peserta didik. Makin jelas tujuan maka makin besar pula motivasi dalam belajar.

2. Hadiah

Hadiah akan memacu semangat mereka untuk bisa belajar lebih giat lagi. Berikan hadiah untuk peserta didik yang berprestasi. Di samping itu, peserta yang belum berprestasi akan termotivasi untuk bisa mengejar peserta didik yang berprestasi.

3. Saingan/kompetisi

Guru berusaha mengadakan persaingan di antara peserta didiknya untuk meningkatkan prestasi belajarnya, berusaha memperbaiki hasil prestasi yang telah dicapai sebelumnya.

4. Pujian

Peserta didik yang berprestasi sudah sewajarnya untuk diberikan penghargaan atau pujian. Pujian yang diberikan bersifat membangun. Dengan pujian peserta didik akan lebih termotivasi untuk mendapatkan prestasi yang lebih baik lagi.

5. Hukuman

Cara meningkatkan motivasi belajar dengan memberikan hukuman. Hukuman akan diberikan kepada peserta didik yang berbuat kesalahan saat proses belajar mengajar. Hukuman ini diberikan dengan harapan agar peserta didik tersebut mau merubah diri dan berusaha memacu motivasi belajarnya. Bentuk hukuman yang diberikan kepada peserta didik adalah hukuman yang bersifat mendidik seperti mencari artikel, mengarang dan lain sebagainya.

6. Membangkitkan dorongan kepada peserta didik untuk belajar

Strateginya adalah dengan memberikan perhatian maksimal ke peserta didik. Selain itu, guru juga dapat membuat peserta didik tertarik dengan materi yang disampaikan dengan cara menggunakan metode yang menarik dan mudah dimengerti peserta didik.

7. Membentuk kebiasaan belajar yang baik

Kebiasaan belajar yang baik dapat dibentuk dengan cara adanya jadwal belajar.

8. Membantu kesulitan belajar peserta didik, baik secara individual maupun kelompok.

Membantu kesulitan peserta didik dengan cara memperhatikan proses dan hasil belajarnya. Dalam proses belajar terdapat beberapa unsur antara lain yaitu penggunaan metode untuk 
menyampaikan materi kepada para peserta didik. Metode yang menarik yaitu dengan gambar dan tulisan warna-warni akan menarik peserta didik untuk mencatat dan mempelajari materi yang telah disampaikan.

9. Menggunakan metode yang bervariasi.

Meningkatkan motivasi belajar dengan menggunakan metode pembelajaran yang variasi. Metode yang bervariasi akan sangat membantu dalam proses belajar dan mengajar. Dengan adanya metode yang baru akan mempermudah guru untuk menyampaikan materi pada peserta didik.

10. Menggunakan media pembelajaran yang baik, serta harus sesuai dengan tujuan pembelajaran.

Beberapa usaha yang perlu dilakukan oleh guru guna membangkitkan motivasi belajar peserta didik menurut Sukmadinata (2003:71), diantaranya sebagai berikut:

1. Menjelaskan manfaat dan tujuan dari pelajaran yang diberikan.

2. Memilih materi atau bahan pelajaran yang betul-betul dibutuhkan oleh peserta didik.

3. Memilih cara penyajian yang bervariasi sesuai dengan kemampuan peserta didik dan banyak memberikan kesempatan kepada peserta didik untuk mencoba dan berpartisipasi.

4. Memberikan kesempatan kepada peserta didik untuk sukses.

5. Berikanlah kemudahan dan bantuan dalam belajar.

6. Berikanlah pujian, ganjaran, atau hadiah (reward).

7. Penghargaan terhadap pribadi anak.

Namun perlu disadari betul oleh para guru akan pentingnya mehamai konsep ketika mengajar. Karena apapun strateginya jika masalah konsep tidak dipahami benar-benar maka tidak akan didapat hasil belajar yang optimal, apalagi memotivasi peserta didik (Subiyakto, 2016:151).

Metode Role Playing apabila dilakukan dengan baik oleh guru tentunya akan mempermudah guru dalam proses pembelajaran sejarah, selain memberikan motivasi belajar kepada peserta didik tentunya peserta didik akan memahami betapa pentingnya pelajaran sejarah. Berdasarkan beberapa tinjauan kekurangan dari metode Role Playing diantaranya adalah apabila guru tidak memahamai langkah-langkah pekaksanaan metode ini, akan mengacaukan berlangsungnya pemeranan. Maka dari itu guru harus memahami betul-betul langkah-langkah dalam penerapan metode Role Playing. 


\section{PENUTUP}

Metode pembelajaran Role Playing bisa dijadikan sebagai metode yang bisa diterapkan oleh guru sejarah pada pembelajaran sejarah di SMA agar bisa menumbuhkan motivasi belajar peserta didik, sehingga stigma peserta didik akan pelajaran sejarah yang awalnya dianggap kurang menarik dan terlalu menoton jadi sangat termotivasi ketika guru menerapkan metode tersebut.

Selain itu, dengan guru menerapkan metode Role Playing dalam pembelajaran sejarah akan membuat peserta didik mempelajari kehidupan tokoh-tokoh yang telah dipentaskanya. Dan tentunya metode ini juga dapat meningkatkan kerjasama antar peserta didik.

\section{DAFTAR PUSTAKA}

Abbas, E. W. (2016). Membangun Nasionalisme Melalui Pembelajaran Sejarah: Kajian Materi Muatan (sejarah) Lokal "Musyawaraatutthalibin” di Kalimantan Selatan.

Astuti, W. (2016). Pendidikan Karakter Dalam Pembelajaran Sejarah Pada Sekolah Menengah Atas (SMA) di Wilayah Pedesaan dan Perkotaan di Kabupaten Cilacap. Skripsi. Semarang: Jurusan Sejarah, FIS UNNES.

Barkley, dkk. (2012). Collaborative Learning Techniques. Bandung: Nusa Media.

Fathurrohman, dkk. (2007). Strategi Belajar Mengajar. Bandung: Refika Aditama.

Kasmadi, Hartono. 1996. Model-model dalam Pengajaran Sejarah. Semarang: Ikip Semarang Press.

Kochar, S.K. (2008). Pembelajaran Sejarah "Teaching of History” (terj: Drs. H. Purwanta, M.A., Yovita Hardiwati). Jakarta: PT Grasindo anggota Ikapi.

Leba, U. T. I., \& Padmomartono, S. (2013). Profesi Pendidikan. Yogyakarta: Ombak.

Mutiani, dkk. (2019). Penerapan Transcript Based Lesson Analyses (TBLA) Sebagai Upaya

Peningkatan Pembelajaran Sejarah Di Sma Negeri 7 Banjarmasin.

Roestiyah. (2008). Strategi Belajar Mengajar. Jakarta: Rineke Cipta.

Prawitasari, M. (2015). Metode Pembelajaran Hypnoteaching Melalui Mind Mapping dalam Pembelajaran Sejarah (Studi Pada Siswa Kelas XI IPS SMA PGRI 6 Banjarmasin).

Putro, H. P. N. (2016). Nilai-Nilai Kebangsaan dalam Pembelajaran Sejarah. In: Developing Education Based on Nationalism Values: The Proceding in Internasional Seminar Building Education Based on Nationalism Values.

Sanjaya, W. (2006). Strategi Pembelajaran Berorientasi Standar Proses Pendidikan. Jakarta: Kencana Prenadamedia Group. 
Sanjaya, W. (2010). Strategi Pembelajaran Berorientasi Standar Proses Pendidikan. Jakarta: Prenada Media Group.

Subiyakto, B. (2016). Strategi Guru dalam Menamamkan Nasionalisme Kepada Peserta Didik. In: Developing Education Based on Nationalism Values: The Proceding of International Seminar Building Education Based on Nationalism Values.

Sukmadinata, N. S. (2003). Landansan Psikologi Proses Pendidikan. Bandung: Remaja Rosdakarya.

Suryaningtyas, A. (2014). Implementasi Metode Pembelajaran Role Playing untuk meningkatkan Motivasi Belajar Pada Standar Kompetensi Mengelola Sistem Kearsipan Siswa Kelas XI Administrasi Perkantoran 2 SMK Negeri 2 Purworejo. Skripsi. Yogyakarta: Program Studi Pendidikan Administrasi Perkantoran, FE UNY.

Susanto, H. (2014). Kemampuan Berpikir Kritis dalam Pedagogi Sejarah Sebagai Upaya Membangun Karakter Peserta Didik. In: Building Nation Character Through Education: Proceeding Internasional Seminar on Character Education.

Susanto, H. (2014). Seputar Pembelajaran Sejarah; Isu, Gagasan dan Strategi Pembelajaran. Yogyakarta: Aswaja Pressindo.

Susanto, H. (2017). “Pemahaman Sejarah Daerah Dan Perspesi Terhadap Keberagaman Budaya Dalam Membina Sikap Nasionalisme" (Studi Korelasi pada Mahasiswa Pendidikan Sejarah FKIP Unlam). Sejarah dan Budaya: Jurnal Sejarah, Budaya, dan Pengajarannya, 9(1), 39-50. 